\title{
Reflections on work addiction as a symptom of contemporary social unrest
}

\begin{abstract}
The main objective of this paper is to present a set of reflections on the addiction to work as a symptom of the social unrest of our post-industrial era. The methodology used was the documentary analysis of recent publications on work addiction. The results show that the personal, organizational, job position (tasks and responsibilities) and employment in general, as well as the process of organizational socialization and the management of interpersonal relationships with managers are triggers of addictive behavior. The partial conclusions indicate that the addictive behavior of salaried workers is configured as a coping strategy to the anxiety, stress, anxiety and psychological suffering generated by the fear of losing the work manifested in the perception of high contemporary labor instability.
\end{abstract}

Keywords: addiction to work, occupational health, work psychology, labor malaise and social symptom
Volume 4 Issue I - 2017

\author{
Néstor Raúl Porras Velásquez,' Laura Camila \\ Parra D'aleman ${ }^{2}$ \\ 'National University of Colombia, Colombia \\ ${ }^{2}$ Los Libertadores University Foundation, University in Bogotá, \\ Colombia
}

Correspondence: Néstor Raúl Porras Velásquez, Psychologist at the National University of Colombia, Currently a professor and researcher at the faculty of psychology of the Libertadores University Foundation, Bogotá. Member of the Free Association in Colombia, Email nrporrasv@libertadores.edu.co, n.porras.69@hotmail.com

Received: October 10, 2017| Published: November 08, 2017

\section{Introduction}

"Addiction is a compulsive behavior that seeks immediate satisfaction but not a mental illness", "Addictions are the substitute for a primary satisfaction. That is, they are a compulsion to repetition". Néstor Raúl Porras Velásquez.

At present and based on the studies and scientific literature consulted we can say that the addiction to work is part of this set of new addictions. That in psychological terms is a psychological addiction of the cognitive-behavioural order. In other words behavioural/ emotional, which unlike chemical addiction to a drug, the addiction to work does not have a "substance". For this reason, when we talk about addiction from clinically/social perspective, the outlook is very broad and we delimit according to the types of addiction that have been proposed so far by the investigators of this phenomenon. In a nutshell, addiction to work is more of a compulsive behaviour than a mental illness. The concept of workaholism may also be associated with a priori behaviours or behaviour that are healthy and not dangerous. These behaviours can become addictive, depending on the intensity, frequency or amount of time and money that the person invests in carrying them out and seriously interfere with the functioning of the subject. We refer, for example, to repetitive and excessive behaviours such as: internet use, sex, work, shopping, food, gambling, among others.

It is evident that the human being tends to repeat the behaviours that produce satisfactory or pleasant consequences, that is why certain behaviours can generate behaviours addictive. In short, a behaviour becomes addictive, when the subject loses control before the beginning or cessation of behaviour, develops a dependence (it is not easy to stop thinking about such behaviour), the interest in other activities that disappear previously it was pleasurable, maintains the behaviour despite being aware of its negative consequences and experiences a feeling of discomfort when it cannot perform such behaviour (abstinence syndrome). To the above, it is necessary to initially add a set of risk factors to develop an addiction: difficulty in coping with everyday problems, low self-esteem, impulsivity, non- tolerance of unpleasant physical or psychological stimuli such as pain or sadness, depressed mood or dysphoria and the search for strong feelings increase the predisposition and vulnerability for a subject to develop an addiction.

Finally, a behaviour becomes addictive, when the subject loses control before the beginning or cessation of behaviour, develops a dependency (it is not easy to stop thinking about such behaviour), the interest in other activities that previously disappeared was pleasurable, maintains the behaviour despite being aware of its negative consequences and experiences a feeling of discomfort when it cannot perform such behaviour (abstinence syndrome). With these introductory elements to the subject in question, we next address the particular aspects of adding to work in contemporary work contexts.

\section{General aspects of addiction to work}

The addiction to work is a topic that today draws attention not only to professionals and researchers of human behaviour at work but to the staff dedicated to health in general. The interest in studying, understanding and explaining this labour phenomenon has to do not only with the implications but also with the personal, social and organizational repercussions that such behaviour entails as a psychosocial risk factor intra and extra labour for the health of the working population. At present, the world of work has undergone a series of changes not only at the technological level, but also in the conditions of employment that directly affect a large number of people who are currently working, and indirectly, those who aspire to enter the labour market. The companies in their eagerness to adapt to the new demands of the global market generate new demands and demands for the employees that translate into increasingly complex transformations of the labour activities. Both the emotional work and the more frequent social interactions with a greater number of people in their daily tasks (peers, bosses, suppliers, clients, etc.), affect both the health and well-being of workers and negatively affect the efficiency of productive organizations, since they become agents that generate work stress, emotional exhaustion and job exhaustion. On the other hand, both flexibilization and job insecurity show in many regions 
of the world new labour market conditions, where formalization of informal work becomes the norm and workers are forced to accept worse conditions in their workplaces.

Finally, among the new realities of contemporary work, we can mention the following: the merger and disappearance of large and especially small enterprises, which generate labour instability and uncertainty about the future of the work, as well as loss of control over personal life projects and family that are reflected in a kind of existential vacuum because of the lack of meaning of the work done. For this reason, Marx's phrase is included at the beginning of the text, which can guide those who legislate or direct the areas of human talent management in companies in our country, in matters of decent and decent working conditions. This paper initially addresses the concepts of work psychology and occupational health psychology as a frame of reference for analyzing psychosocial risk factors and work addiction.

\section{Psychology of work}

According to Leplat \& Cuny, ${ }^{1}$ the name industrial psychology is perhaps the most common and used in many countries. However, "the term" work psychology "is clearly being imposed against the traditional term of industrial psychology, more identified with Taylorism and the strict economic optimization of industrial labor". ${ }^{1}$ From the perspective of these two French psychologists, talking about work psychology is much more pertinent and adequate than industrial-organizational psychology, since the object of study of that discipline is more precise. According to these authors, objectively speaking: A psychological science of work is not, and cannot be, a simple mechanism to increase the profitability that the company (whether private or state) gets out of work. It is first and foremost a science that investigates all aspects of work, an activity developed by a person (worker) in interaction with other people and machines. ${ }^{1}$ For the purposes of this research it is considered pertinent to assume the psychology of work as a field of basic and/or applied research, and a field of professional specialization.

For Morán ${ }^{2}$ the psychology of work is "a specific field of psychology that aims at the scientific study of the behavior of individuals in the work environment". ${ }^{2}$ In short, according to this Spanish psychologist, work psychology studies human behaviour in its individual and social dimension, in work-related situations. In the same sense, Blanch ${ }^{3}$ argues that: "the very nature of work psychology is inseparable from the socio-historical construction of problematic realities which as a discipline seeks to understand theoretically and which as a profession seeks to solve and change in the practice". ${ }^{3}$ It is evident to these authors that the psychology of work and organizations does not exist in the social vacuum. This aspect has been approached previously by Porras. ${ }^{4-7}$

Authors such as Peiró, Prieto \& Roe; ${ }^{8}$ Agulló \& Blanch ${ }^{3}$ recognize that work psychology shares two basic principles: A thematic area structured around personal-organizational or work environment interaction, which in some cases appears under the name work behaviour that behavioural reaction to variations in the circumstances of the environment-work context) and, in other cases, as a labour action of a cognitive, emotional and social subject intentionally oriented to modify their socio-labour environment, and a same concept of work as a singular form of employment. In other words, work as a socially and historically determined form of wage labour activity, under a contractual regime, and within the framework of a particular form of work organization. ${ }^{9}$ Pereda, Berrocal \& Alonso $^{10}$ point out that social, political, economic, scientific and technological changes have had a significant impact both on the role, responsibilities and roles assigned to the work psychologist, as well as on models and techniques that this as a social agent uses in his professional activity interventora and investigativa. However, however drastic those changes may have been, according to the authors mentioned: Psychology, with its scientific methods and theories remains the conceptual basis of work psychology, and yet the psychologist has had to expand his activity to aspects related to other disciplines such as economics, labour law, occupational medicine, etc., both when working individually and when doing it as part of multidisciplinary teams..$^{10}$ The warning is directed mainly towards those psychologists and psychologists who assume occupational psychology as an administrative practice of human resources.

On the other hand, according to Blanch, ${ }^{3}$ the psychology of work as a discipline and as a profession aims to study "the psychosocial phenomena and processes involved in the interaction of the employed person with his working environment". ${ }^{3}$ This author acknowledges that traditionally a purely personal-personal perspective has been taken to analyze how ordinary people think, feel and value working in the employment system and what psychosocial impact their work situation produces (employment, underemployment or unemployment). For this reason, it proposes a broader sociocultural study perspective where the rigorous look and critical analysis of the work psychologist focuses on the psychosocial aspects of work activity in a specific organizational context.

Porras $^{6,11}$ shows how the limits and the configuration of this specialized field of psychology applied to the world of work have economic and political interests that transcend the purely scientific interest of understanding labour reality. In this sense, the marked instrumental interest of discourse and psychological practices in the field of work are clearly stated by Pulido ${ }^{12}$ when he argues that: Since psychology encountered the world of work in the first decades of the twentieth century, research has pointed out that its place and operations are linked to both the liberal capitalist society and the civilization project, and thus colonizer of modernity. ${ }^{12}$ For this author, the ideological load of the practices and discourses of "scientific" psychology in the contemporary world of work and its close connection with neoliberal policies is undeniable. For the time being, it is considered that the information reviewed is sufficient to indicate the multiplicity of aspects addressed by the psychology of work, as well as the diversity of approaches used for the analysis of the behaviour or behaviour of people at work.

\section{Occupational health psychology}

According to Gil-Monte, ${ }^{13}$ occupational health psychology is a new specialty of basic and applied psychology that results from the integration of the contents of public health with preventive medicine, clinical psychology and health psychology, applied in the context of work and organizations. For this author: Fostering the psychosocial health in the workplace is to promote the public health of the population, as people of working age spend most of their time in the wake of work or work in their home. For this reason, the promotion of occupational health and the prevention of occupational diseases and accidents related to psychosocial risks should be a public health issue for governments. ${ }^{13}$ Consequently, generating healthy work environments and caring for the health of the people who work is increasing the productivity and effectiveness of organizations. However, for many people today, wage labour (employment) is no longer what it was 
before and not even as it was before. That is, the meanings of work and conditions have changed drastically. From stable and regulated employment, continuous and prolonged throughout the active life of a person that allowed him to set up a professional career, we have moved on to job instability and uncertainty, unlimited flexibilization and the precariousness of work activity. To work is not only to produce or sell the labour force. It is to do it within a framework of social norms that define what is employment and what is not, what is a good job and what is not, and so on. This framework of legal and social regulations in which labour activity is organized in practice turns the labour market into a social institution, which shows that the employment norm as a rule of social insertion has changed profoundly in the last three decades. But this fact also means that transformations in the world of work have profound and structural effects on the conditions of production of modern societies.

In general terms, it is easy to see that labour activity is always subject to very different variables and the set of all of them form what we now call labour conditions. However, one of the determining factors of working conditions is the economic factor. That is, the fixed salary, supplements, overtime and any element that influences the salary. Another factor related to working conditions is safety and hygiene. At this point, new parameters have been incorporated in the last years, from the policies of occupational risks, that is, rules and guidelines that should govern an activity so that it has sufficient guarantees of physical security for the worker, as well as for his Health. On the other hand, taking into account the social valuation of work, as well as the motivations to work. It is not an exaggeration to say that work is a determinant of mental health. In addition to being a source of income, work provides people with a series of elements that influence emotional balance, a level of activity, a structure of daily time, a development of creative expression, an exchange of social relations and a personal identity, as well as a sense of utility. ${ }^{3}$ On the other hand, job satisfaction - understood as the measure in which a person obtains well-being from his work - is an important variable related to mental health. ${ }^{14}$ This dimension, according to this author, is related both to working conditions (in particular, employment status and salary) and to behaviour in the same (absenteeism and rotation of jobs, mainly).

\section{Psychosocial risk factors}

Psychosocial risk factors refer to those conditions that are present in a work situation and that are directly related to the organization, the content of the work and the accomplishment of the task, and that has the capacity to affect either the welfare or the physical, psychological or social health of the worker, such as the development of work. In other words, psychosocial risk factors are all those working conditions likely to cause harm to workers' health. According to the Joint Committee of the International Labour Office ${ }^{15}$ and the World Health Organization, ${ }^{16}$ psychosocial factors consist of: interactions between, on the one hand, the work, the environment and the conditions of organization, and on the other, the worker's capacities, his needs, his culture and his personal situation outside the work, all through perceptions and experiences, can influence health, performance and job satisfaction. ${ }^{16}$

In addition to salary, safety and health, there are other conditions that equally influence the way to do a job. The schedule is one of them, and there are several modalities, because a company needs to cover a productive schedule and, in parallel, workers have to make their activity and free time compatible. The incentive policy is undoubtedly another aspect of the totality of working conditions, and it does not refer exclusively to remuneration, but takes into account the internal promotion of employees. All these aspects must be taken over by human resources management to ensure not only compliance with existing labour legislation but decent and decent work conditions that in the long run become a strategic advantage compared to their competence in the labour market.

According to Moreno Jiménez, ${ }^{17}$ work has historically been a health risk and working conditions have usually posed a health threat that have led to accidents and diseases related to health of all kinds, including of course the mental health of workers. Although concern for occupational hazards has historically focused on physical and environmental risks, more attention has recently been paid to the psychosocial risks that human resource investigators in work contexts require, a greater effort in conceptualization and forms of manifestation. Particularly in present times, due to the expansion of the services market and to globalization, psychosocial risks have increased and intensified, and their health effects are significant. For this reason, the management or human resources management requires integral attention to occupational health.

\section{Definitions of addiction to work}

Most psychologists agree that Oates ${ }^{18}$ was the first to use the term "workaholism" to refer to a type of behaviour, which he observed in himself when he was working, and which resembled the behaviour in alcoholism, because of their compulsive nature and lack of control, and that could become a risk to their personal health, their interpersonal relationships and their social functioning in general. Oates ${ }^{18}$ defined work addiction as an excessive and uncontrollable need to work incessantly that affects the health, happiness, and interpersonal relationships of the addict. According to Salanova et al..$^{19}$ the causes of this problem "point to social, personal and labour conditions that interact and cause the worker to be affected by this addiction in a specific labour context". ${ }^{19}$ Cherrington defines work addiction broadly as an irrational implication of overwork that characterizes people who are unable to find another source of occupation other than their own work. Killinger ${ }^{20}$ argues that "a workaholic is a person who gradually loses emotional stability and becomes addicted to control and power in a compulsive attempt to achieve approval and success". ${ }^{20}$

According to Robinson, ${ }^{21}$ work addiction is characterized by continuous, voluntary and compulsive labor overload, so that the worker is unable to regulate his work habits and ends up excluding other fields of interest and activity from his vital social world. Salanova et al., ${ }^{19}$ define addiction to work as a psychosocial damage characterized by overwork due mainly to an irresistible need or drive to work constantly. More recently, it has been argued that addiction to work "is an irresistible internal impulse to work very hard, that is, addicts work excessively and compulsively". ${ }^{22}$ According to these authors, there are currently four criteria to define the workaholic: to have a special work attitude, to dedicate excessive time and effort to work, to suffer a compulsive and involuntary disorder to continue working (inclusive criteria) and to show general disinterest for any activity other than the strictly labour (exclusive criterion). In short, and for the purposes of our research the concept of workaholism refers to a type of compulsive and uncontrollable behaviour to work, which affects the labour relations, social and mental health of the affected person. However, we recognize in advance that this is a recent concept and that there is, to date, a single definition and accepted by all connoisseurs and researchers on the subject. 


\section{Types of addiction to work}

Naughton, ${ }^{23}$ presents a typology of the workaholic based on the dimension of involvement in the professional career and obsessive compulsive behaviour. Naughton, ${ }^{23}$ proposes two basic types:

i. The addict and involved in work worker characterized by a high degree of commitment at work, and intensive dedication to work to the detriment of other relationships and interests.

ii. The Addicted and Obsessive Worker, characterized by a high degree of commitment and an amount of energy devoted to work does not correspond to results.

Other typologies, proposals are:

a. Ambitious worker

b. Ruthless fight

c. Taxation

d. Competitive worker

e. Need to feel superior

f. Worker blamed

g. Work overload as an ethical imperative

h. Unsafe worker

i. Continuous and eager pursuit of approval and self-esteem.

j. Isolated and solitary worker.

k. Professional relationship as a substitute for interpersonal relationship (Rohrlich). These types (classifications) not currently have an empirical validation.

\section{Characteristics of a person addicted to work}

According to Bryan Robinson, ${ }^{21}$ a person addicted to work is characterized by:

a. Work in a compulsive manner

b. Inability to relax after work

c. Need to control and do things his way

d. Gives more importance to work than to relationships with others

e. Is not able to delegate or finds it very difficult

f. Their self-assessment is focused on the results of the work (tasks) rather than on the process of how those results have been achieved. To this list it is necessary to add: that the work for these people is an obsession.

\section{Psychosocial profile of the workaholic}

According to Castañeda \& García, ${ }^{22}$ the psychosocial profile of the workaholic includes the following traits: denying the situation, manipulating information, poor interpersonal communication, high need for control, provision for extra work, performing unnecessary tasks to justify his excess of work, presence (going to work when sick), extra labour problems, work habits that exceed what is prescribed, his goal at work is always perfection among others.

\section{Behaviours associated with work addiction}

According to the results of the research conducted by Salanova et al. ${ }^{19}$ it is possible to affirm that a worker with a problem of addiction to work presents the following behaviours associated with addiction: he works more than 56 hours a week without a hitch, works late at night without rest, works even while sick, takes work home on a regular basis, cannot refuse additional tasks, their topic of conversation, bases their self-esteem on the recognition by his work requires praise and permanent recognition of his work, he does not enjoy free time, vacation or rest, free time causes anxiety and anxiety, high need for control, among other behaviours.

\section{Addictive behaviour to work}

The studies of the addictive behaviour to the work have been characterized, throughout the history, by a wide amount of theoretical, conceptual, methodological and instrumental positions. This situation has led to a variety of opinions among occupational health professionals, including psychologists and researchers on this particular phenomenon, regarding how to consider such behaviour. On the one hand there are those who consider it as positive and favourable behaviour for the organization of the same type of so-called "work involvement" or commitment to tasks and organization. ${ }^{24}$ For other psychologists, addiction to work is considered to be a negative behavior: ${ }^{20}$ finally, there are those who consider that this addiction can have positive and negative consequences depending on certain characteristics of the personality or level of commitment to the organization, such as Spencer \& Robins. ${ }^{25}$

Generally speaking, addictions are poorly considered; however, addiction to work is often reinforced, social, economic and personal, and is considered socially as a "clean addiction." Not surprisingly, several authors have pointed out that "in our current society of production and consumption, an important part of our identity comes from our profession and work, and a great part of our time is spent and consumed at work". ${ }^{26}$ In this case, it is possible to speak of good social addictions (socially accepted, recognized, valued and even desirable in the majority of people who work and wish to keep their jobs). Of course, this absurdity is no more than a comfortable reading, perversity of capitalist logic.

However, in the context of globalization of markets, corporate culture demands a higher dedication to its employees, sometimes supposedly voluntary, sometimes imposed by real working conditions and can exceed rational functional limits. For this group of psychologists at the Autonomous University of Madrid, work addiction is a well-known fact and of great importance both in the workplace and in personal life, but insufficiently studied. On the other hand, when the number of hours of work increases considerably and absorbs all the capacity of dedication of the person, when the work takes the form of obsessive and compulsive dedication, when the person seems to define their social roles exclusively by their relation to work and manifests himself incapable to enjoy with other areas of life; for many psychologists it is often referred to as "work addiction". However, neither its definition nor the explanatory theoretical models are sufficiently established and clarified. ${ }^{27}$

Fernández-Montalvo \& Echeburua, ${ }^{28}$ after reviewing the main aspects involved in work addiction. They conceptualize this disorder as a psychological addiction and expose the psychopathological aspects that characterize it. In addition, they suggest possible ways 
of intervention, based on the results obtained in other types of psychological addictions. Finally, it is important to acknowledge that Polo Santiago, Navarro \& Alí, ${ }^{29}$ which for many people today, work is one of the most significant areas in life, since: From this it is possible the development of the potentialities, the human capacities and the obtaining of some tangible and intangible conditions that contribute to the quality of life of the human being. This is evident when it is understood that man is the only being able to work, not only for his subsistence, but also to achieve his own transcendence. ${ }^{29}$ For this reason, psychologists can argue that work in its psychological dimension structures the subjectivity of people as a horizon of meaning and life.

For Polo, Santiago, Navarro \& Alí29 work involves a physical, psychological, emotional and social commitment on the part of the individual in the accomplishment of the activities; therefore, more than a simple action that is elaborated daily, this becomes an undeniable human reality that benefits both the individual and society; however, any element that hinders the relationship between man and his work will negatively impact the development of the person, leading to pathologies that affect both the psyche and the corporeality of being as the means of production of the organization and the constitution of the society. ${ }^{29}$ In other words, beyond the economic dimension human work implies a psychological, emotional and social commitment of the person with his community for this reason the loss of employment entails psychologically the breaking of the bond and social recognition of the subject by the community to which it belongs.

\section{Final thoughts}

According to what we found, we can say that in the addiction to work, there are psychological traits and aspects of the work context, particularly the intra and extra labour conditions. In addition, the balance between hours of work, leisure and rest is decisive for personal well-being. However, in today's society, called by many as the consumer society, leisure time is discarded in favour of additional work increase profits to increase consumption. In other words, this is the context where a "new" psychological disorder has begun to be studied which is characterized by the loss of control in the work activity and that is denominated: the addiction to work.

Linked to the above, we find that the widespread use of new technologies and the fear of losing employment aggravate the problem. For we cannot forget that psychology as a scientific discipline and social practice assumes work from the relations of capitalist production. Therefore, it can be deduced that psychology is a direct product of the transformation of man into commodity, product of the social division of labour. Where labour is considered productive, insofar as it produces capital, it enters the circuit of commodity production, realizes surplus value, enters circulation and produces more value, as Marx put it since the beginning of the twentieth century.

\section{Conclusion}

Both job addiction and burnout and mobbing are just three of the current manifestations of the effects of the new working conditions on the mental health of Workers. This is the scenario of a labour market that displaces people between job insecurity and social exclusion. For this reason, we conclude this document by pointing out that addiction to work is not a disease but a symptom of the social unrest of our time, which must be studied by work psychologists and organizations as well as health psychologists. In the current conditions of wage labour (employment), understood as the set of psychological, social, economic, legal, technological, etc. characteristics. In the context of which the work activity is carried out. Emerging new work experiences and new forms of work relationships, which influence, decisively on the daily lives of working people and on the organizational dynamics. For this reason, any study of insertion into the "new", "dynamic" and "changing" labour market must consider the changes that have occurred in society in general and in production systems in particular.

According to the current working conditions, it is pertinent to ask ourselves as occupational health professionals. What is the link between the social protection system and the labour market in Colombia? Since the answer to this question gives us insights on the relationship between labour insertion, unemployment, informal employment and social and labour vulnerability of people in conditions of vulnerability. In addition, this analysis allows us to articulate the socioeconomic context and the effects on the mental health of workers in our country. As for the work ethic, understood by Bauman, ${ }^{30}$ as an aberrant rudeness, by holding the poor responsible for their poverty because of their lack of willingness to work and, therefore, to their immorality and personal degradation. Would become one of the last services of the work ethic to the society of consumers; where the "new poor" are those who are unable to access consumption and the novelty of the capitalist system. ${ }^{31-35}$

\section{Acknowledgements}

None.

\section{Conflict of interest}

The author declares no conflict of interest.

\section{References}

1. Lepat J, Cuny X. Psicología del trabajo: enfoques y técnicas. Madrid: Pablo del Rio, Spain; 1978

2. Morán C. Psicología del trabajo: nociones introductorias. Málaga: Ediciones Aljibe. 2005;20(2):279-280.

3. Blanch J. Psicología social del trabajo. In: Aguilar M, Reid A, Editors. Tratado de psicología social: Perspectivas socioculturales. Anthropos, Barcelona, México; 2007. p. 210-240.

4. Porras N. Elementos básicos para el análisis de la cultura de las organizaciones desde la psicología. Tesis psicológica. 2009;4(1):36-56.

5. Porras N. La Gerencia del potencial humano en las organizaciones que aprenden desde la perspectiva psicológica. Revista Electrónica de psicología social Poiésis. 2012;23:1-11.

6. Porras N. El estudio del comportamiento organizacional como fundamento para la gestión humana por competencias. Revista Electrónica de psicología social Poiésis. 2014;27:1-12.

7. Porras N. Aproximación histórica a la psicología del trabajo y de las organizaciones en Colombia. Revista Interamericana de Psicología/Interamerican Journal of Psychology. 2016;50(3):317-330.

8. Peiró J Prieto F, Roe R. Tratado de psicología del trabajo. Vol. I: Aspectos psicosociales del trabajo, Síntesis, Madrid, Spain; 1996. 447 p.

9. Porras N. Límites y retos del campo de la psicología de las organizaciones. En Revista Electrónica de psicología social Poiesis. 2012;24:1-14.

10. Pereda S, Berrocal F, Alonso M. Psicología del trabajo. Síntesis, Madrid, Spain; 2008. 
11. Porras N. ¿Qué es lo que hace exactamente un psicólogo organizacional? Una reflexión crítica desde las teorías del rol. En Revista Electrónica de psicología social Poiesis. 2013;25:1-9.

12. Pulido C. Psicología y trabajo: una relación bajo examen. En: Ballesteros B, Escobar H, Editors. Psicología y políticas públicas: aportes desde la academia. Bogotá: Editorial Universidad Javeriana, Spain; 2011. p. 123-144.

13. Gil-Monte P. Riesgos psicosociales en el trabajo y salud ocupacional. Rev perú Med Exp salud publica. 2012;29(2):237-241.

14. Muchinsky P. Psicología aplicada al trabajo. 7th ed. Thomson, México; 2007. $488 \mathrm{p}$.

15. Oficina Internacional del Trabajo (OIT). Panorama laboral de América Latina y el Caribe. Oficina regional, Lima-Perú, 2002. 120 p.

16. Salud mental: un estado de bienestar. Organización Mundial de la salud (OMS), Geneva, 2013.

17. Moreno Jiménez B. Factores y riesgos laborales psicosociales: conceptualización, historia y cambios actuales. Medicina y Seguridad del Trabajo. 2011;57 Suppl 1:4-19.

18. Oates W. Confessions of a Workaholic: The facts about work addiction. World Publishing Co, New York, USA; 1971.

19. Salanova M, Del Líbano M, Llorens S, et al. La adicción al trabajo. Nota Técnica de Prevención, 759, 22. ${ }^{a}$ Serie. Instituto Nacional de Seguridad e Higiene en el Trabajo, Spain, 2008. p. 1-6.

20. Killinger B. La adicción al trabajo. Paidós, Barcelona, Spain; 1993. 296 p.

21. Robinson BE, Post P. Risk of addiction to work and family functioning. Psychological Reports. 1997;81(1):91-95.

22. Castañeda E, García J. Perspectivas actuales de la adicción al trabajo. Psicología y Salud. 2011;21(1):131-139.

23. Naughton TJ. A conceptual view of workaholism and implications for career counseling and research. Career Development Quarterly. 1987;35(3):180-187.
24. Del Líbano M, Llorens S, Schaufeli W, et al. Adicción al trabajo: concepto y evaluación. Gestión Práctica de Riesgos Laborales. 2006;27:24-31.

25. Spence JT, Robinson A. Workaholism: Definition, measurement, and preliminary results. J Pers Assess. 1992;58(1):160-178.

26. Moreno B, Gálvez M, Garrosa E, et al. La adicción al trabajo. Psicología Conductual. 2005;13(3):417-428.

27. Harpaz I, Snir R. Workaholism: Its definition and nature. Human Relations. 2003;56(3):292-320.

28. Fernández-Montalvo J, Echeburúa E. Laborodependencia: cuando el trabajo se convierte en adicción. Revista de Psicopatología y Psicología Clínica. 1998;3(2):103-120.

29. Polo JD, Santiago V, Navarro MC, et al. Creencias irracionales, síndrome de Burnout y adicción al trabajo en las organizaciones. Psicogente. 2016;19(35):148-160.

30. Bauman Z. Trabajo, consumismo y nuevos pobres. Gedisa, Barcelona, Spain; 2005. p. 3-75.

31. Castillo J, Gómez M. Excessive work or addiction to work: workaholism in a Colombian company. Pilot study trough application of DUWAS test. Revista Ciencias de la Salud. 2012;10(3):307-322.

32. Escobar J, Bonilla-Jiménez FI. Grupos focales: una guía conceptual y metodológica. Cuadernos hispanoamericanos de psicología. 2009;9(1):51-67.

33. Garrido Piosa M. Adicción al trabajo: características, detección y prevención desde una perspectiva integral. Enfermería Global. 2014;13(1):362369.

34. Hernández R, Fernández C, Baptista P. Metodología de la investigación. McGraw Hill, México; 2002. 656 p.

35. Valenzuela AV, Díaz EM. Adicción al trabajo, satisfacción laboral y familiar en académicos de una universidad estatal chilena. Salud \& Sociedad. 2011;1(3):222-232. 